\title{
Therapeutic potential of $T$ regulatory cell manipulation: advantages and limitations
}

\author{
ANA I. NEAGU ${ }^{1}$, CRISTINA MAMBET ${ }^{1}$, LAURA G NECULA ${ }^{1}$, LILIA MATEI ${ }^{1,2}$, DENISA L. \\ DRAGU ${ }^{1,2}$, MARIUS ATAMAN ${ }^{1}$, GEORGIANA G. PETRICA-MATEI ${ }^{3}$, IRINA ALEXIU ${ }^{1}$, \\ SAVIANA NEDEIANU ${ }^{1}$, CORALIA BLEOTU ${ }^{1}$, MIHAI STOIAN ${ }^{1}$, CARMEN C. DIACONU, ${ }^{1, *}$
}

\author{
${ }^{1}$ Stefan S. Nicolau Institute of Virology, MyeloAL Program, Bucharest, Romania \\ ${ }^{2}$ Research Institute of University of Bucharest, Bucharet, Romania \\ ${ }^{2}$ Personal Genetics Ltd., Bucharest, Romania
}

\begin{abstract}
Regulatory $\mathrm{T}$ cells have a central role in maintaining immune homeostasis by modulating immune responses and promoting tolerance to self-antigens. Treg cells are involved in autoimmune disease prevention, suppression of allergic diseases, confinement of infection-induced immunopathology, induction of fetal-maternal and oral tolerance. On the other hand, Treg suppressor function limits the host effector responses in cancer and chronic infections, promoting tumor progression and pathogen persistence. Although a significant number of studies in animal models revealed promising therapeutic potential of Treg cells, translation to clinical application is still at the beginning. Manipulation of Treg cells has proved to be beneficial in different autoimmune diseases, pre-malignant and malignant disorders (e.g., myeloproliferative neoplasms, other types of hematological disorders and solid cancers), graft-versus-host disease and graft rejection after hematopoietic stem cell or solid organ transplantation. Targeted Treg cell therapies (either by depletion or immune-checkpoint blockade) might be promising strategies for immunotherapy in cancer, by improving anti-tumor immune response, and also in chronic infections, contributing to control of infections by effector T cells.
\end{abstract}

Keywords Regulatory $\mathrm{T}$ cells (Treg cells, Tregs), clinical trial, immune surveillance, inflammation, animal model, transplant.

To cite this article: RAZMI NEAGU AI, MAMBET C, NECULA LG, MATEI L, DRAGU DL, ATAMAN M, PETRICA-MATEI GG, ALEXIU I, NEDEIANU S, BLEOTU C, STOIAN M, DIACONU CC. Therapeutic potential of T regulatory cell manipulation: advantages and limitations. Rom Biotechnol Lett. 2020; 25(2): 1501-1510. DOI: 10.25083/rb1/25.2/1501.1510

$\triangle$ *Corresponding author: CARMEN C. DIACONU, E-mail: ccdiaconu@yahoo.com; myeloal.ediaprot@yahoo.com All correspondence to be addressed to: Stefan S. Nicolau Institute of Virology, 285 Mihai Bravu, Bucharest 030304, Romania 


\section{Introduction}

Regulatory T cells (Treg cells, Tregs) represent a more recently discovered $\mathrm{T}$ cell population that play a central role in maintaining immune homeostasis by modulating immune responses and promoting tolerance to selfantigens. Treg cells are involved in autoimmune disease prevention, suppression of allergic diseases, prevention of infection-induced immunopathology, induction of fetalmaternal and oral tolerance (CORTHAY [1]). On the other hand, Treg suppressor function limits the host effector responses in cancer and chronic infections, promoting tumor progression and pathogen persistence (WHITESIDE [2]; TOGASHI \& al [3]; ROUSE \& al [4]; BOTEZATU [5]). Although a major progress has been made in understanding Treg biology, the phenotypic and functional complexity of these cells requires additional in vitro and in vivo studies to establish their role in both normal and pathological conditions, in order to use them as therapeutic tools.

A significant number of studies in animal models revealed promising therapeutic potential of Treg cells, but translation to clinical application is still at the beginning (HAHN \& al [6]). In recent years, animal models have been commonly used for Treg therapy in a range of disorders such as: inflammatory and autoimmune diseases, metabolic disorders, cancer, or in transplantation tolerance studies. Since Treg studies on human subjects have limitations (regarding the reduced number of Treg cells, lack of specific markers or the impossibility to study certain tissues), extensive research on Treg cells has been performed in murine models; moreover, the humanized mouse model (representing mouse transplanted with human cells/tissues) offers a better opportunity to examine human Treg biology and mechanisms of involvement in various pathologies, therefore to use therapeutic potential of those cells [6].

Treg cell manipulation has proved to be beneficial in different autoimmune diseases, pre-malignant and malignant disorders (e.g., myeloproliferative neoplasms, other types of hematological disorders and solid tumors), graft-versushost disease (GvHD) and graft rejection after hematopoietic stem cell transplantation (HSCT) and solid organ (kidney (VAN DER NET \& al [7]), liver (JEFFERY \& al [8])) transplantation. A very recent study revealed, in a murine model, that Tregs promoted oligodendrocyte differentiation and accelerated myelination and re-myelination even in the absence of inflammation, and therefore suggested a regenerative function of Tregs in the central nervous system (DOMBROWSKI \& al [9]). Targeted Treg cell therapies (either by depletion or immune-checkpoint blockade) might be promising strategies for immunotherapy in cancer, by improving anti-tumor immune response, and also in chronic infections (NISHIKAWA \& al [10]; NIZAR \& al [11]), contributing to control of infections by effector T cells.

\section{Treg cell manipulation strategies}

There are two main and opposite approaches of Treg cell manipulation for therapeutic purposes: expansion and depletion. Moreover, not only the global frequency of Treg cell can be influenced, but also their function could be enhanced or diminished, or a particular Treg subset could be modulated in order to obtain clinical benefit.

In clinical conditions such as autoimmune and allergic diseases, graft rejection after solid organ transplantation or hematopoietic stem cell transplantation, it is necessary to restore immune tolerance. In this regard, Treg cell generation and expansion protocols in vitro and in vivo have been established, not only for polyclonal Tregs, but also for antigen-specific Tregs. Several strategies for polyclonal Treg cells expansion in vivo have been tested; they require administration of IL-2 and IL-2-anti-IL-2 complexes, intravenous immunoglobulin, neutralizing inflammatory cytokines or rapamycin (ZHANG \& al [12]).

Adoptive Treg cellular therapy consists in isolation of Tregs or naïve $\mathrm{T}$ cells from patient blood, ex vivo expansion/induction and expansion, and re-injection into person. In order to generate antigen-specific Treg cells in vitro, Treg cells are stimulated with antigen-pulsed dendritic cells (DC) or anti-CD3/anti-CD28-coated beads and high-dose IL-2. Other strategies imply either infection of naïve $\mathrm{T}$ cells with a retrovirus containing either both Foxp3 and TCR genes, or polyclonal Treg infection with a retrovirus with TCR transgene; antigen-specific Treg cells could also be obtained in vitro by treating naïve CD4+ T cells with TGF- $\beta$. Several protocols of generating antigenspecific Treg cells from naïve $\mathrm{T}$ cells in vivo have been developed, each one requiring TGF- $\beta$ : stimulation with antigen plus DC, antigen pulsed ethylene carbodiimide (ECDI)-fixed cells, and apoptosis-antigen therapy - a novel ingenious approach that combine immune cell apoptosis and autoantigen-specific Treg generations by self-peptide administration (KASAGI \& al [13]).

In cancer and chronic infections, strategies for Treg depletion or suppressive function alteration might be beneficial in restoring immune effector function. AntiCD25 monoclonal antibody (daclizumab) was one of the most extensively studied agents used for Treg depletion in vivo and in clinical trials. Other Treg depleting agents such denileukin diftitox (a fusion protein that combine IL-2 and diphtheria toxin) or cyclophosphamide proved to be efficient in certain types of cancer. A phase II clinical trial on stage IV melanoma patients (TELANG \& al [14]) concluded that administration of diphtheria toxin-IL-2 fusion protein induced a transient depletion of CD25+ Tregs, followed by repopulation with cytotoxic CD8+ $\mathrm{T}$ cells specific for melanoma antigens and regression of metastases (RASKU \& al [15]). Immune checkpoints inhibitors such as anti-CTLA-4 monoclonal antibody lower 
the number and function of Treg, contributing to antitumoral immune response (TAKEUCHI \& al [16]; CURIEL [17]).

\section{Clinical applications of Tregs}

\section{Autoimmune diseases}

Several studies provided evidence regarding the involvement of Tregs in various autoimmune disorder pathogenesis. A significant impairment in the number and function of Treg cells has been reported in multiple sclerosis (MS) (VENKEN \& al [18]), autoimmune liver diseases (primary biliary cirrhosis, primary sclerosing cholangitis and autoimmune hepatitis (LIBERAL \& al [19]), ankylosing spondylitis (GUO \& al [20]), type 1 diabetes mellitus (GHONAIM \& al [21]), and in disorders associated with autoimmune manifestations as for example some of the myeloproliferative neoplasms (MPN) (WANG $\&$ al [22]); moreover, Tregs display the capacity to convert into effector $\mathrm{T}$ cells in inflammatory condition/status or to secrete pro-inflammatory cytokine IL-17 in the presence of IL-1 $\beta$ and IL-6 (WANG \& al [22]; CVETANOVICH $\&$ al [23]; KOENEN \& al [24]; BERIOU \& al [25]).

Manipulation of Treg cells with the purpose of restoring immune tolerance seemed to be beneficial in autoimmune disease treatment; an important limitation however, was the reduced frequency of these cells in the peripheral blood. This triggered the attempt of many research teams to establish proper methods of raising Treg levels in the periphery. Recent approaches regarding this challenge highlighted some procedures suitable to generate in vivo and in vitro augmented levels of Treg cells (ZHANG \& al [12]).

In order to treat autoimmune diseases, different procedures of Treg cell expansion have been imagined and tested. Although these procedures can represent useful strategies for autoimmune disease therapy, the risk of inducing the suppression of entire immune system should not be neglected.

Webster et al (WEBSTER \& al [26]) imagined an in vivo procedure to induce the expansion of Treg cells: by injecting experimental autoimmune encephalomyelitis (EAE) mice (the experimental model of MS) with IL2-antiIL2mAb complexes during three consecutive days. An important increase in Treg cell number in different organs such as liver, gut, spleen, lymph nodes and thymus, was observed. The increase in Treg level lasted for 1-2 weeks and the expanded cells showed a very good activation. Furthermore, administration of IL-2-anti-IL2complexes as pretreatment, proved to be protective against EAE in mice, suggesting that this procedure can help not only the treatment of autoimmune diseases but also the organ transplantation, because it enhances the immune tolerance (WEBSTER \& al [26]).

Low doses of IL-2 injected for 5 days in NOD mice with induced type 1 diabetes, reversed the disease, mainly by increasing Treg cells function in pancreas (GRINBERG-BLEYER \& al [27]).
A study aiming to establish the role of Treg: Teff ratio in diabetes development and, also, the importance of IL-2 dose for stimulating mainly Treg cells, found out that the amount of Tregs is inversely related to the amplitude of islet infiltration; the most diminished percentage of Treg cells was identified in prediabetic mice with mild-moderate (grade 1-2) insulitis. This relative reduction of Treg cells amount in Langerhans islets preceded the inflammatory process augmentation, and mirrored an imbalance of Treg : Teff ratio, affecting the immune homeostasis (TANG $\&$ al [28])

The therapeutic effect on Treg cell number and function was linked to the IL-2 dose. On one hand, high doses of IL-2 led to an augmentation of both the effector $\mathrm{T}$ cells frequency and Tregs, promoting autoimmune tissue destruction, on the other hand, low doses of IL-2 stimulated mainly Treg cells, having a very weak action on $\mathrm{T}$ effector CD4+, CD8+ and NK cells. Pretreatment of mice with low doses of IL-2 during week 5-20 or 10-20 impeded disease development (TANG \& al [28]).

Intravenous immunoglobulin G (IVIg) administration is another therapeutical approach that increases Treg cell number in vivo through DC activation (TRINATH \& al [29]).

Injection of intravenous immunoglobulin in mice prevented the development of EAE, augmented Treg cell population and intensified their suppressive function. The same treatment proved to be inefficient in Tregdepleted mice, thus pointing out a direct effect of IVIg on preexisting Tregs, instead of de novo induction of Tregs from conventional Tcells (EPHREM \& al [30]). This finding suggested a potential clinical application of IVIg in MS and other autoimmune diseases. A recent study evaluated Treg cells before and after IVIg treatment in patients with autoimmune rheumatic diseases (such as dermatomyositis, polymyositis). Treg cells were significantly expanded in patients blood 48 to 96 hours after IVIg administration (BAYRY \& al [31]). During acute phase of Kawasaki disease the number of Tregs was very low; IVIg therapy raised both Foxp3 mRNA and protein level of expression (BAYRY \& al [31]; OLIVITO \& al [32]).

A multitude of studies revealed, both in vitro and in vivo, the efficiency of immunosuppressive drug rapamycin in induction of nTreg accompanied by $\mathrm{T}$ effector suppression in autoimmune disorders. In the animal model of RR-EAE (relapsing-remitting EAE), oral or intraperitoneal administration of rapamycin at the peak of disease or at the end of the first clinical attack, alleviated the disease symptoms and attenuated demyelination and axonal loss (ESPOSITO \& al [33]).

In EAE, engineered Tregs suppressed ongoing encephalomyelitis reducing disease symptoms (FRANSSON $\&$ al [34]). In a very recent study it was shown that induction of myelin oligodendrocyte glycoprotein (MOG) - specific Foxp3+ Tregs through gene therapy restored immune tolerance in mice (KEELER \& al [35]).

In a recent investigation, Haque et al., showed that, in murine model, adoptive transfer of functional Treg 
cells derived from induced pluripotent stem (iPS) cells significantly reduced host immune responses and decreased RA development (HAQUE \& al [36]).

Another study evaluated in collagen-induced arthritis mice the therapeutic potential of antigen specific thymus-derived nTregs and TGF- $\beta$-induced Tregs (iTregs). The results highlighted that in mice with established autoimmunity TGF- $\beta$-induced iTregs are more stable and functional than nTregs [24].

\section{Tregs manipulation for re-establishment of immune-surveillance: from pre-malignant to malig- nant disorders - myeloproliferative neoplasms (MPN)}

Most myeloproliferative neoplasms (MPN) have as distinctive features the disturbed JAK -STAT signaling pathways and elevated levels of inflammatory cytokines. These disorders are able to mimic benign hematopoietic disorders that mask a clone of a modified hematopoietic stem cells capable to transform into an acute leukemia (SPIVAK [37]).

Inflammatory signals, released in response to different stressors, such as infection, or chronic rheumatologic conditions, can induce HSCs to release cytokines that promote myeloid differentiation. After triggering stress myelopoiesis, intracellular signaling programs need to be deactivated and return to steady state. Excessive exposure to inflammatory cytokines, may exhaust HSC due to continued cycling. This promotes bone marrow failure, and can induce preleukemic to leukemic transformation (HEMMATI \& al [38]).

Immune signature is only partly described in MPN and in spite of more than a decade of using JAK inhibitors for these diseases, their effect on different immune subsets of cells is not completely clear.

It has been described the myelofibrosis (MF), including primary myelofibrosis (PMF), or post-essential thrombocythemia, and post-polycythemia vera, is associated with autoimmune manifestations.

Tregs are significantly lower in MPN patients compared to healthy controls and decrease even more after treatment with JAK inhibitors (KEOHANE \& al [39]). JAK inhibitors induced a functional silencing of $\mathrm{T}$ effectors cells as a result of blocking the secretion of proinflammatory cytokines, both in vivo and in vitro (WANG \& al [22]). It was speculated that treatment might induce a polarization from a Treg phenotype to a TH17 phenotype, and re-establishment of immune-surveillance against the malignant clone. Further investigation is necessary to confirm the hypothesis that expanded TH17 cells originate from Tregs or previously "silenced" CD4 T cells.

Ruxolitinib, a JAK inhibitor, inhibits Treg cells sIL2R $\alpha$ production in MF patients which might explain the ruxolitinib effect on relieving constitutional symptoms. Plasma sIL2R $\alpha$ levels were correlated to the autoimmune serology in MPN patients. These findings suggested that sIL2R $\alpha$ is significantly involved in autoimmune manifestations seen in patients with MF (WANG \& al [22]).

Pegylated-interferon alpha $(\mathrm{PegINF} \alpha)$ treatment of patients with polycythemia vera (PV) and essential thrombocythemia (ET) has resulted in long-term clinical response, decreased JAK2V617F allelic burden and restoration of polyclonal hematopoiesis. Beneficial effects of PegINF $\alpha$ might be attributed to increased frequency of peripheral blood CD4+ Foxp3+ regulatory T cells (Treg), alongside to direct suppression of JAK2-mutated clone, induction of dormant stem cells to proliferation, and augmentation of an immune effect against PV and ET clones. PegINF $\alpha$ increased the number of highly suppressive Treg, characterized by co-expression of CD39 and HLA-DR. The same team observed also that PegINF $\alpha$ increased the frequency of PD-1+ CD4+ helper cells and PD-1+ CD4+ Foxp3+ Treg cells. Augmentation of Ki-67+ Treg, HLA-DR+ CD39+ Treg, Helios+ Treg and HLA-DR+ CD38+ CD8+ T cells associated also with an increase in JAK2V617F allelic burden (KOVACSOVICSBANKOWSKI \& al [40]).

\section{Cancer immunotherapies}

Over the last years, a growing number of studies have pointed out the involvement of Treg cells in immune evasion and cancer progression (NISHIKAWA \& al [10]; CHAUDHARY \& al [41]). Tregs, along with cancerassociated fibroblasts and myeloid-derived suppressor cells, participate in the immunosuppressive activity of tumor microenvironment. Particularly, Treg suppress the immune responses against self-antigens and the anti-tumor responses of the host immunity system. As such, the selective depletion of intra-tumor Tregs, by identification and targeting the molecules characteristic for these cells, represents a way to modify the balance from the immune suppression to immune activation against tumor cells in the human body (FINOTELLO \& al [42]).

Currently, several strategies to deplete tumor-infiltrating Tregs or to affect their functions have been developed or are currently in development. Among them, low-dose chemotherapy, CD25-targeted antibodies, immune checkpoint inhibition (ICI), chemokine receptor blockade, and blockade of suppressive mechanisms and soluble mediators (IL-10/TGF- $\beta$ ) are the main approaches. Still, these strategies could have impact also on effector T cells leading to therapy side effects (CHAUDHARY \& al [41]).

CD-25 (IL-2 receptor $\alpha$-chain) is constitutively expressed on Treg cells and is considered as a suitable target for Treg depletion. However, this molecule is also expressed on effector $\mathrm{T}$ cells. As such, an anti-CD25 therapy can damper the Treg depletion effect by reducing also activated effector T cells (NISHIKAWA \& al [10]; RAKEBRANDT \& al [43]). Moreover, depletion of Treg cells by targeting CD25 could cause autoimmune diseases (RAKEBRANDT \& al [43]).

Recently, Plitas et al (PLITAS \& al [44]) identified chemokine receptor 8 (CCR8) as a marker of tumorinfiltrating Tregs in breast cancer and suggested its targeting for the depletion of Treg cells as a promising immunotherapeutic approach in the treatment of this type of cancer. This molecule was identified as a potential target also in colorectal cancer (ANGELOVA \& al [45]), as well as in lung cancer, angiosarcoma, and melanoma 
(FINOTELLO \& al [42]). The expression of CCR8 on Tregs was correlated with poor prognosis in cancer (PLITAS \& al [44]; ANGELOVA \& al [45]; DE SIMONE $\&$ al [46]). On the other side, CCR8 is also expressed in liver and cardiac tissues and targeting this molecule could induce severe adverse effects (FINOTELLO \& al [42]).

Also, De Simone et al reported, along with CCR8, interleukin-1 receptor 2 (IL1R2), programmed death (PD)-1 Ligand1, and PD-1 Ligand2 as specific signature molecules expressed on the cell surfaces of tumorinfiltrating Treg in colorectal and non-small-cell lung cancers (DE SIMONE \& al [46]).

Other molecule highlighted as a potential target is CCR4 specifically expressed on Treg cells from melanoma, as well as GITR (glucocorticoid-induced TNF-receptor family related protein) and $\mathrm{OX} 40$, a co-stimulatory molecule of the TNF receptor family, both being constitutively expressed on Treg cells, but transitory expressed on other T cells (NISHIKAWA \& al [10]).

Although a major progress has been achieved, a better comprehension of the biology of Tregs in tumor microenvironment is needed as an important step in the development of new immune-targeting therapies in order to improve their outcome ensuring higher efficacy and minimal side effects.

\section{Treg therapy in solid organ transplantation}

For those patients having end-stage organ failure, the solid organ transplantation could be the last choice of treatment in order to improve morbidity and mortality and hope for an increased quality of life. Such treatment became available during the last 50 years for various types of organs (SAYEGH \& al [47]).

Although solid organ transplantation have been remarkable improved by advancements in surgery and drugs, allotransplantation is still vulnerable to graft rejection. Moreover, an accelerated increase in morbidity and mortality associated with the toxicity of immunosuppressive drugs it is reported. In this regard, the main alternative therapeutic approach is the induction of immunological tolerance based on the manipulation of immune cells so that the immunological environment sustains the graft survival, without interfering with crucial immune surveillance mechanisms and, concurrently, abolishing immunosuppressant-related toxicity (VAIKUNTHANATHAN \& al [48]; ROMANO \& al [49]).

The concept of Treg therapy in organ transplantation seems to be an important approach. Tregs can be generated in vivo by pre-treating mice with a donor alloantigen along with a non-depleting anti-CD4 monoclonal antibody. This treatment results in the development of Tregs able to prevent allograft rejection in vivo. These Tregs can also prevent allograft rejection in naïve mice by cellular adoptive transfer. Tregs can be also obtained in vitro by culturing CD4+ T cells with donor alloantigen and antiCD4 antibody (ISSA \& al [50]).

In vitro and in vivo studies demonstrated that CD4+CD25+Foxp3+ Tregs which have a critical role in the maintenance of self-tolerance and prevention of autoimmune disease seems to contribute to the establishment and maintenance of operational tolerance to renal allografts (DOUSDAMPANIS \& al [51]). A study conducted in preclinical animal models showed that the infusion of ex vivo expanded recipient Tregs can sustain indefinite acceptance of heart allografts in murine models (WHITEHOUSE \& al [52]). Moreover, the infusion of Treg cells in combination with immature dendritic cells induces alloantigen tolerance and prolongs liver allograft survival (HE \& al [53]).

Studies investigating the liver, kidney or lung transplantation have showed that patients with increased number of circulating and intrahepatic Tregs present significant tolerance to the transplanted organ and a stable graft function compared to non-tolerant or healthy individuals (LAM \& al [54]).

Isolation, multiplication and administration of human Tregs in human transplant recipients are investigated in several Phase I/II trials especially regarding the safety and efficacy of this therapeutic approach since all studies sustain that Tregs are able to promote transplantation tolerance. The approach of the trials involve purification of naturally occurring regulatory $\mathrm{T}$ cells from living-donor organ transplant recipients, the growth of the cells in the laboratory and re-infusion of these cells into the patient, several days after organ transplantation (VAIKUNTHANATHAN \& al [48]; ROMANO \& al [49]; PROSSER \& al [55]).

Some aspects should be considered during Tregs cells therapy in organ transplantation: specific immunological characteristics of transplanted organ, optimal dose of Tregs, the optimal time for Treg administration relative to time of transplant, frequency of administration, purity of Treg cells, possibility to evaluate Treg efficiency in transplant environment.

\section{Tregs in prevention of GvHD after allogeneic hematopoietic stem cell transplantation}

Allogeneic hematopoietic stem cell transplantation (aHSCT) is a powerful therapeutic strategy with high curative potential for many hematological cancers and genetic disorders. However, its success is often dampened by the development of GvHD, a severe complication with an acute or chronic clinical course, associated with significant morbidity and mortality (GHIMIRE \& al [56]). In terms of pathogenesis, GvHD is caused by the activation of donor $\mathrm{T}$ cells that react against the host HLA antigens leading to inflammation and tissue damage (FERRARA $\&$ al [57]). Intensive immunosuppressive regimens are currently used to prevent GvHD but they lack immunological specificity and have only partial efficacy (GAIDOT $\&$ al [58]).

Numerous studies were conducted to establish the role of different Treg populations in GvHD suppression. The efficiency of nTreg cells to prevent GvHD was demonstrated in several animal models (HOFFMANN \& al [59]; TAYLOR \& al [60]), but the applicability of this method is limited by the high Treg doses required for treatment (HIPPEN \& al [61]). The used 
of in vitro-differentiated iTregs proved to be ineffective in reduced GvHD (BERES \& al [62]).

Another approach to prevent GvHD after allogeneic bone marrow transplantation is represented by the utilization of engineered Tregs obtained from CD4+CD25-T cells that ectopically express Foxp3 after lentiviral transduction (CAO \& al [63]).

As proven by studies on murine models and phase I/II clinical trials, cell-based therapies that employ Treg are able to prevent GvHD occurrence by suppressing the alloimmune responses through a direct action on conventional T cells contained in the graft (LECLERC \& al [64]; MATTA \& al [65]). The preliminary results are promising as Treg administration does not hinder the graft-versus tumor effect as well as the capacity of post-transplant immune reconstitution (LECLERC \& al [64]).

It has been demonstrated that approximately an equal number of freshly isolated donor Tregs must be timely added to donor $\mathrm{CD} 3+\mathrm{T}$ cells in order to ensure a successful GvHD prophylaxis (GAIDOT \& al [58]). Due to the fact that thymus-derived Treg are present at a very low number in the peripheral blood of the donor, their isolation and purification are technically difficult and additional expansion protocols are needed (RAMLAL \& al [66]).

Different strategies for in vitro expansion of donor Treg have been attempted. As an example, an increase in the Treg number and purity was achieved by cultivating for 7-12 days the Tregs isolated from unstimulated leukapheresis products (THEIL \& al [67]). Another strategy was to obtain recipient-specific Treg through culturing the purified cells obtained from donor mice in the presence of irradiated recipient-type splenocytes and recombinant murine IL-2. This approach led to a better control of GvHD in mice compared to polyclonal Treg administration (GAIDOT $\&$ al [58]). In a recent study it was shown that the pretransplantation exposure of donor T-cells to activated protein $\mathrm{C}(\mathrm{aPC})$ induced an increase of Treg frequency via aPC-protease-activator receptors 2 and 3 (PAR2/PAR3) signaling, protecting HSCT recipients from GvHD (RANJAN \& al [68]).

To overcome the difficulty related to the low frequency of Tregs obtained from a single donor, thirdparty derived Tregs were used as an alternative for GvHD therapy. The ex vivo studies showed that the third-party Tregs displayed an immunosuppressive effect similar to donor Tregs, having the advantage that they can be prepared and tested for activity in advance. Although third-party Tregs had a shorter survival rate after adoptive transfer in comparison to donor Tregs they were able to control conventional $\mathrm{T}$ cell proliferation in the first two days after aHSCT (PIERINI \& al [69]).

In addition to in vitro expansion of Treg, in vivo protocols to stimulate Treg proliferation have been used too. In this respect, administration of CD4+ invariant natural killer $\mathrm{T}$ cells (iNKT) in low-doses promoted donor Treg in vivo expansion (SCHNEIDAWIND \& al [70]). A similar effect was obtained in a bone marrow transplantation murine model after treating donor mice with an agonistic antibody for death receptor 3 (DR3,
TNFRSF25), a molecule that is part of tumor necrosis factor (TNF) receptor superfamily (KIM \& al [71]).

Many efforts were focused on enhancing Treg immunosuppresive activity rather than increasing their number. Several procedures were attempted, such as: activation of tTregs by employing the CD4-binding human immunodeficiency virus-1 protein gp120 (SCHLODER \& al [72]); targeting by inhibitory antibodies DNAX accessory molecule 1 (DNAM-1) activating receptor, a molecule expressed predominantly by NK and CD8+ T cells, in order to increase Treg efficacy and control GvHD (KOYAMA \& al [73]); Treg genetic modification by inducing expression of chimeric antigen receptor (CAR) that targets the HLA class I molecule A2 to suppress alloimune reactions (EDINGER [74]).

\section{Treg therapy in other clinical conditions}

Several recent studies showed the advantages of using antigen-specific Tregs vs polyclonal Treg cells in therapy. Unlike polyclonal regulatory $\mathrm{T}$ cells, suppressive activity of antigen-specific $\mathrm{T}$ regs is directed toward diseaseassociated antigens and they perform their function at the site of inflammation. Currently two strategies are employed in order to obtain antigen-specific $\mathrm{T}$ regulatory cells: engineered transduced TCRs and CAR.

Expanded human polyclonal Foxp3+ Treg cells transduced with a recombinant TCR from a hemophilia A patient's T-cell clone, effectively induce immunosuppression of $\mathrm{T}$ and $\mathrm{B}$ cell responses against $\mathrm{F}$ VIII, used as replacement therapy in Hemophilia A (KIM \& al [75]).

In contrast with TCR-transduced Tregs, F VIIIspecific CAR Tregs are not subjected to MHC restriction, thus having the potential to be used to every patient with anti-FVIII antibody, irrespective of MHC type (YOON $\&$ al [76]).

Another condition in which Treg cells might be useful is atherosclerosis (ASC) (FOKS \& al [77]). In mouse models as well as in humans suffering from ASC lesions, frequencies of Treg cells are reduced compared to healthy controls, and their function proved to be altered (DE BOER \& al [78]; MOR \& al [79]). T regulatory cells have important atheroprotective properties by suppression of activation of cells involved in atherogenic processes like $\mathrm{T}$ cells, DC, macrophages, endothelial cells; therefore they represent a potential therapeutic tool in prevention of cardiovascular disease. Several approaches have been attempted to induce Treg cells and tune the balance between proatherogenic inflammatory factors and protective antiatherogenic Tregs: in vivo induction of Treg cells by IL-2/anti IL-2 monoclonal antibody intraperitoneal injections proved favorable effects by interfering with initial atherosclerosis development stages and suppression of inflammation; on pre-existing lesions Tregs improved stability of atherosclerotic plaques (FOKS \& al [80]).

Suppression of atherosclerotic lesions in animal models has been obtained also by intranasal, oral, or subcutaneous administration of oxidized LDL, HSP60, and ApoB100 peptide-relevant atherosclerosis antigens 
having the potential to induce antigen specific Tregs (LI \& al [81]; VAN PUIJVELDE \& al [82]).

\section{Perspectives, limitations, conclusions}

The moment of intervention relative to disease stages, optimal dose of Treg or therapeutical agent administered, selection of the suitable Treg subset, and expansion method, are of great importance when setting a clinical Treg strategy; furthermore, Treg plasticity may be responsible for losing Foxp3 expression and suppressive function when in vitro protocols are used for Treg expansion (CVETANOVICH \& al [23]). Successful therapies require a deeper knowledge of Treg immunobiology; combination therapies for Treg modulation in autoimmune diseases, transplantation, and cancer, might generate superior results (CABELLO-KINDELAN \& al [83]; TANAKA \& al [84]). While targeting Tregs showed clinical benefits in anti-tumor immunity, the potential side effects of Treg should also be taken into consideration: depletion strategies or decreasing Treg function might induce autoimmune reactions. Although many studies concerning therapeutic potential of Tregs were performed in animal models, there were also attempts to use Tregbased cellular therapies in humans leading to several early stage clinical trials.

As a prominent example, the ONE study (launched in 2011), a multicentric phase I/II clinical trial, explore cellular therapy in renal transplantation ([85]). Patients from 6 different countries were evaluated between 2014 and 2017 in order to investigate the feasibility of Good Manufacturing Practice (GMP) of regulatory immune cells for clinical use and safety of cell infusion. The ONE Study aims to produce immune cells compatible with the patient's body that will naturally suppress the immune response against the transplanted organ. The cells, which are introduced at the beginning of the transplantation procedure, would result in a significant reduction in the use of immunosuppressive drugs, thus diminishing not only potential side effects and the risk of malignancy, but also the cost of health care and ensure an overall improvement in patient quality of life ([85]). Lessons resulted from this large clinical trial will be valuable for medical research teams and for national regulatory agencies to design future clinical trials in order to ensure the highest efficiency of Treg therapy.

\section{Acknowledgements}

We gratefully acknowledge the funding from the project POC A1.1.4. ID: P_37_798, Contract 149/26.10.2016, (MySMIS2014+: 106774).

\section{References}

1. A. CORTHAY. How do regulatory T cells work? Scand $J$ Immunol, 70 (4), 326-336 (2009).

2. T.L. WHITESIDE. The role of regulatory T cells in cancer immunology. Immunotargets Ther, 4, 159-171 (2015).
3. Y. TOGASHI, H. NISHIKAWA. Regulatory T Cells: Molecular and Cellular Basis for Immunoregulation. Curr Top Microbiol Immunol, 410, 3-27 (2017).

4. B.T. ROUSE, P.P. SARANGI, S. SUVAS. Regulatory T cells in virus infections. Immunol Rev, 212, 272-286 (2006).

5. A. BOTEZATU, IV. IANCU, A. PLESA, D. MANDA, O. POPA, M. BOSTAN, M. MIHAILA, A. ALBULESCU, AL. FUDULU, SV. VLADOIU, I HUICA, R DOBRESCU, G ANTONA, C BADIU. Methylation of tumour suppressor genes associated with thyroid cancer Cancer Biomarkers 25 53-65 (2019).

6. S.A. HAHN, I. BELLINGHAUSEN, B. TRINSCHEK, C. BECKER. Translating Treg Therapy in Humanized Mice. Front Immunol, 6, 623 (2015).

7. J.B. VAN DER NET, A. BUSHELL, K.J. WOOD, P.N. HARDEN. Regulatory T cells: first steps of clinical application in solid organ transplantation. Transpl Int, 29 (1), 3-11 (2016).

8. H.C. JEFFERY, M.K. BRAITCH, S. BROWN, Y.H. OO. Clinical Potential of Regulatory $\mathrm{T}$ Cell Therapy in Liver Diseases: An Overview and Current Perspectives. Front Immunol, 7, 334 (2016).

9. Y. DOMBROWSKI, T. O'HAGAN, M. DITTMER, R. PENALVA, S.R. MAYORAL, P. BANKHEAD, S. FLEVILLE, G. ELEFTHERIADIS, C. ZHAO, M. NAUGHTON, R. HASSAN, J. MOFFAT, J. FALCONER, A. BOYD, P. HAMILTON, I.V. ALLEN, A. KISSENPFENNIG, P.N. MOYNAGH, E. EVERGREN, B. PERBAL, A.C. WILLIAMS, R.J. INGRAM, J.R. CHAN, R.J.M. FRANKLIN, D.C. FITZGERALD. Regulatory $\mathrm{T}$ cells promote myelin regeneration in the central nervous system. Nat Neurosci, 20 (5), 674-680 (2017).

10. H. NISHIKAWA, S. SAKAGUCHI. Regulatory T cells in cancer immunotherapy. Curr Opin Immunol, 27, 1-7 (2014).

11. S. NIZAR, J. COPIER, B. MEYER, M. BODMANSMITH, C. GALUSTIAN, D. KUMAR, A. DALGLEISH. T-regulatory cell modulation: the future of cancer immunotherapy? Br J Cancer, 100 (11), 16971703 (2009).

12. D. ZHANG, E. TU, S. KASAGI, P. ZANVIT, Q. CHEN, W. CHEN. Manipulating regulatory T cells: a promising strategy to treat autoimmunity. Immunotherapy, 7 (11), 1201-1211 (2015).

13. S. KASAGI, P. ZHANG, L. CHE, B. ABBATIELLO, T. MARUYAMA, H. NAKATSUKASA, P. ZANVIT, W. JIN, J.E. KONKEL, W. CHEN. In vivo-generated antigen-specific regulatory $\mathrm{T}$ cells treat autoimmunity without compromising antibacterial immune response. Sci Transl Med, 6 (241), 241ra278 (2014).

14. S. TELANG, M.A. RASKU, A.L. CLEM, K. CARTER, A.C. KLARER, W.R. BADGER, R.A. MILAM, S.N. RAI, J. PAN, H. GRAGG, B.F. CLEM, K.M. MCMASTERS, D.M. MILLER, J. CHESNEY. Phase II trial of the regulatory $\mathrm{T}$ cell-depleting agent, denileukin diftitox, in patients with unresectable stage IV melanoma. BMC Cancer, 11, 515 (2011).

15. M.A. RASKU, A.L. CLEM, S. TELANG, B. TAFT, K. GETTINGS, H. GRAGG, D. CRAMER, S.C. LEAR, K.M. MCMASTERS, D.M. MILLER, J. CHESNEY. 
Transient $\mathrm{T}$ cell depletion causes regression of melanoma metastases. J Transl Med, 6, 12 (2008).

16. Y. TAKEUCHI, H. NISHIKAWA. Roles of regulatory T cells in cancer immunity. Int Immunol, 28 (8), 401-409 (2016).

17. T.J. CURIEL. Regulatory T cells and treatment of cancer. Curr Opin Immunol, 20 (2), 241-246 (2008).

18. K. VENKEN, N. HELlingS, R. LIBLAU, P. STINISSEN. Disturbed regulatory T cell homeostasis in multiple sclerosis. Trends Mol Med, 16 (2), 58-68 (2010).

19. R. LIBERAL, C.R. GRANT, M.S. LONGHI, G. MIELIVERGANI, D. VERGANI. Regulatory T cells: Mechanisms of suppression and impairment in autoimmune liver disease. IUBMB Life, 67 (2), 88-97 (2015).

20. H. GUO, M. ZHENG, K. ZHANG, F. YANG, X. ZHANG, Q. HAN, Z.N. CHEN, P. ZHU. Functional defects in CD4(+) CD25(high) FoxP3(+) regulatory cells in ankylosing spondylitis. Sci Rep, 6, 37559 (2016).

21. M.M. GHONAIM, R.H. EL-EDEL, S.M. KAMAL ELDEIN, W.M.M. ABO EL FOTOH, S.S. SALMAN. TRegulatory Cell Subsets in Children with Type 1 Diabetes Mellitus: Relation to Control of the Disease. Endocr Metab Immune Disord Drug Targets, 17 (3), 238-245 (2017).

22. J.C. WANG, H. SINDHU, C. CHEN, A. KUNDRA, M.I. KAFEEL, C. WONG, S. LICHTER. Immune derangements in patients with myelofibrosis: the role of Treg, Th17, and sIL2Ralpha. PLoS One, 10 (3), e0116723 (2015).

23. G.L. CVETANOVICH, D.A. HAFLER. Human regulatory T cells in autoimmune diseases. Curr Opin Immunol, 22 (6), 753-760 (2010).

24. H.J. KOENEN, R.L. SMEETS, P.M. VINK, E. VAN RIJSSEN, A.M. BOOTS, I. JOOSTEN. Human CD25highFoxp3pos regulatory $\mathrm{T}$ cells differentiate into IL-17-producing cells. Blood, 112 (6), 2340-2352 (2008).

25. G. BERIOU, C.M. COSTANTINO, C.W. ASHLEY, L. YANG, V.K. KUCHROO, C. BAECHER-ALLAN, D.A. HAFLER. IL-17-producing human peripheral regulatory T cells retain suppressive function. Blood, 113 (18), 4240-4249 (2009).

26. K.E. WEBSTER, S. WALTERS, R.E. KOHLER, T. MRKVAN, O. BOYMAN, C.D. SURH, S.T. GREY, J. SPRENT. In vivo expansion of $\mathrm{T}$ reg cells with IL-2-mAb complexes: induction of resistance to EAE and long-term acceptance of islet allografts without immunosuppression. J Exp Med, 206 (4), 751-760 (2009).

27. Y. GRINBERG-BLEYER, A. BAEYENS, S. YOU, R. ELHAGE, G. FOURCADE, S. GREGOIRE, N. CAGNARD, W. CARPENTIER, Q. TANG, J. BLUESTONE, L. CHATENOUD, D. KLATZMANN, B.L. SALOMON, E. PIAGGIO. IL-2 reverses established type 1 diabetes in NOD mice by a local effect on pancreatic regulatory T cells. J Exp Med, 207 (9), 18711878 (2010).

28. Q. TANG, J.Y. ADAMS, C. PENARANDA, K. MELLI, E. PIAGGIO, E. SGOUROUDIS, C.A. PICCIRILLO, B.L. SALOMON, J.A. BLUESTONE. Central role of defective interleukin-2 production in the triggering of islet autoimmune destruction. Immunity, 28 (5), 687-697 (2008).
29. J. TRINATH, P. HEGDE, M. SHARMA, M.S. MADDUR, M. RABIN, J.M. VALLAT, L. MAGY, K.N. BALAJI, S.V. KAVERI, J. BAYRY. Intravenous immunoglobulin expands regulatory $\mathrm{T}$ cells via induction of cyclooxygenase-2-dependent prostaglandin E2 in human dendritic cells. Blood, 122 (8), 1419-1427 (2013).

30. A. EPHREM, S. CHAMAT, C. MIQUEL, S. FISSON, L. MOUTHON, G. CALIGIURI, S. DELIGNAT, S. ELLURU, J. BAYRY, S. LACROIX-DESMAZES, J.L. COHEN, B.L. SALOMON, M.D. KAZATCHKINE, S.V. KAVERI, N. MISRA. Expansion of CD4+CD25+ regulatory $\mathrm{T}$ cells by intravenous immunoglobulin: a critical factor in controlling experimental autoimmune encephalomyelitis. Blood, 111 (2), 715-722 (2008).

31. J. BAYRY, L. MOUTHON, S.V. KAVERI. Intravenous immunoglobulin expands regulatory $\mathrm{T}$ cells in autoimmune rheumatic disease. J Rheumatol, 39 (2), 450-451 (2012).

32. B. OLIVITO, A. TADDIO, G. SIMONINI, C. MASSAI, S. CIULLINI, E. GAMBINERI, M. DE MARTINO, C. AZZARI, R. CIMAZ. Defective FOXP3 expression in patients with acute Kawasaki disease and restoration by intravenous immunoglobulin therapy. Clin Exp Rheumatol, 28 (1 Suppl 57), 93-97 (2010).

33. M. ESPOSITO, F. RUFFINI, M. BELLONE, N. GAGLIANI, M. BATTAGLIA, G. MARTINO, R. FURLAN. Rapamycin inhibits relapsing experimental autoimmune encephalomyelitis by both effector and regulatory T cells modulation. J Neuroimmunol, 220 (12), 52-63 (2010).

34. M. FRANSSON, E. PIRAS, J. BURMAN, B. NILSSON, M. ESSAND, B. LU, R.A. HARRIS, P.U. MAGNUSSON, E. BRITTEBO, A.S. LOSKOG. CAR/FoxP3-engineered $\mathrm{T}$ regulatory cells target the CNS and suppress EAE upon intranasal delivery. J Neuroinflammation, 9, 112 (2012).

35. G.D. KEELER, S. KUMAR, B. PALASCHAK, E.L. SILVERBERG, D.M. MARKUSIC, N.T. JONES, B.E. HOFFMAN. Gene Therapy-Induced Antigen-Specific Tregs Inhibit Neuro-inflammation and Reverse Disease in a Mouse Model of Multiple Sclerosis. Mol Ther, (2017).

36. R. HAQUE, F. LEI, X. XIONG, Y. BIAN, B. ZHAO, Y. WU, J. SONG. Programming of regulatory T cells from pluripotent stem cells and prevention of autoimmunity. J Immunol, 189 (3), 1228-1236 (2012).

37. J.L. SPIVAK. Myeloproliferative Neoplasms. N Engl J Med, 376 (22), 2168-2181 (2017).

38. S. HEMMATI, T. HAQUE, K. GRITSMAN. Inflammatory Signaling Pathways in Preleukemic and Leukemic Stem Cells. Front Oncol, 7, 265 (2017).

39. C. KEOHANE, S. KORDASTI, T. SEIDL, P. PEREZ ABELLAN, N.S. THOMAS, C.N. HARRISON, D.P. MCLORNAN, G.J. MUFTI. JAK inhibition induces silencing of T Helper cytokine secretion and a profound reduction in T regulatory cells. Br J Haematol, 171 (1), 60-73 (2015).

40. M. KOVACSOVICS-BANKOWSKI, T.W. KELLEY, O. EFIMOVA, S.J. KIM, A. WILSON, S. SWIERCZEK, J. PRCHAL. Changes in peripheral blood lymphocytes in polycythemia vera and essential thrombocythemia patients treated with pegylated-interferon alpha and 
correlation with JAK2(V617F) allelic burden. Exp Hematol Oncol, 5, 28 (2015).

41. B. CHAUDHARY, E. ELKORD. Regulatory T Cells in the Tumor Microenvironment and Cancer Progression: Role and Therapeutic Targeting. Vaccines (Basel), 4 (3), (2016).

42. F. FINOTELlO, Z. TRAJANOSKI. New strategies for cancer immunotherapy: targeting regulatory $\mathrm{T}$ cells. Genome Med, 9 (1), 10 (2017).

43. N. RAKEBRANDT, K. LITTRINGER, N. JOLLER. Regulatory T cells: balancing protection versus pathology. Swiss Med Wkly, 146, w14343 (2016).

44. G. PLITAS, C. KONOPACKI, K. WU, P.D. BOS, M. MORROW, E.V. PUTINTSEVA, D.M. CHUDAKOV, A.Y. RUDENSKY. Regulatory T Cells Exhibit Distinct Features in Human Breast Cancer. Immunity, 45 (5), 11221134 (2016).

45. M. ANGELOVA, P. CHAROENTONG, H. HACKL, M.L. FISCHER, R. SNAJDER, A.M. KROGSDAM, M.J. WALDNER, G. BINDEA, B. MLECNIK, J. GALON, Z. TRAJANOSKI. Characterization of the immunophenotypes and antigenomes of colorectal cancers reveals distinct tumor escape mechanisms and novel targets for immunotherapy. Genome Biol, 16, 64 (2015).

46. M. DE SIMONE, A. ARRIGONI, G. ROSSETTI, P. GRUARIN, V. RANZANI, C. POLITANO, R.J.P. BONNAL, E. PROVASI, M.L. SARNICOLA, I. PANZERI, M. MORO, M. CROSTI, S. MAZZARA, V. VAIRA, S. BOSARI, A. PALLESCHI, L. SANTAMBROGIO, G. BOVO, N. ZUCCHINI, M. TOTIS, L. GIANOTTI, G. CESANA, R.A. PEREGO, N. MARONI, A. PISANI CERETTI, E. OPOCHER, R. DE FRANCESCO, J. GEGINAT, H.G. STUNNENBERG, S. ABRIGNANI, M. PAGANI. Transcriptional Landscape of Human Tissue Lymphocytes Unveils Uniqueness of Tumor-Infiltrating $\mathrm{T}$ Regulatory Cells. Immunity, 45 (5), 1135-1147 (2016).

47. M.H. SAYEGH, C.B. CARPENTER. Transplantation 50 years later--progress, challenges, and promises. $N$ Engl $J$ Med, 351 (26), 2761-2766 (2004).

48. T. VAIKUNTHANATHAN, N. SAFINIA, D. BOARDMAN, R.I. LECHLER, G. LOMBARDI. Regulatory T cells: tolerance induction in solid organ transplantation. Clin Exp Immunol, 189 (2), 197-210 (2017).

49. M. ROMANO, S.L. TUNG, L.A. SMYTH, G. LOMBARDI. Treg therapy in transplantation: a general overview. Transpl Int, 30 (8), 745-753 (2017).

50. F. ISSA, K.J. WOOD. CD4+ regulatory T cells in solid organ transplantation. Curr Opin Organ Transplant, 15 (6), 757-764 (2010).

51. P. DOUSDAMPANIS, K. TRIGKA, A. MOUZAKI. Tregs and kidney: From diabetic nephropathy to renal transplantation. World J Transplant, 6 (3), 556-563 (2016).

52. G.P. WHITEHOUSE, A. HOPE, A. SANCHEZ-FUEYO. Regulatory T-cell therapy in liver transplantation. Transpl Int, 30 (8), 776-784 (2017).

53. W. HE, L. CHEN, L. ZHENG, L. LUO, L. GAO. Prolonged survival effects induced by immature dendritic cells and regulatory $\mathrm{T}$ cells in a rat liver transplantation model. Mol Immunol, 79, 92-97 (2016).
54. A.J. LAM, R.E. HOEPPLI, M.K. LEVINGS. Harnessing Advances in $\mathrm{T}$ Regulatory Cell Biology for Cellular Therapy in Transplantation. Transplantation, 101 (10), 2277-2287 (2017).

55. A.C. PROSSER, A. KALlIES, M. LUCAS. Tissueresident Lymphocytes in Solid Organ Transplantation: Innocent Passengers or the key to Organ Transplant Survival? Transplantation, (2017).

56. S. GHIMIRE, D. WEBER, E. MAVIN, X.N. WANG, A.M. DICKINSON, E. HOLLER. Pathophysiology of GvHD and Other HSCT-Related Major Complications. Front Immunol, 8, 79 (2017).

57. J.L. FERRARA, J.E. LEVINE, P. REDDY, E. HOLLER. Graft-versus-host disease. Lancet, 373 (9674), 1550-1561 (2009).

58. A. GAIDOT, D.A. LANDAU, G.H. MARTIN, O. BONDUELLE, Y. GRINBERG-BLEYER, D. MATHEOUD, S. GREGOIRE, C. BAILLOU, B. COMBADIERE, E. PIAGGIO, J.L. COHEN. Immune reconstitution is preserved in hematopoietic stem cell transplantation coadministered with regulatory $\mathrm{T}$ cells for GVHD prevention. Blood, 117 (10), 2975-2983 (2011).

59. P. HOFFMANN, J. ERMANN, M. EDINGER, C.G. FATHMAN, S. STROBER. Donor-type CD4(+)CD25(+) regulatory $\mathrm{T}$ cells suppress lethal acute graft-versus-host disease after allogeneic bone marrow transplantation. J Exp Med, 196 (3), 389-399 (2002).

60. P.A. TAYLOR, C.J. LEES, B.R. BLAZAR. The infusion of ex vivo activated and expanded CD4(+)CD25(+) immune regulatory cells inhibits graft-versus-host disease lethality. Blood, 99 (10), 3493-3499 (2002).

61. K.L. HIPPEN, S.C. MERKEL, D.K. SCHIRM, C.M. SIEBEN, D. SUMSTAD, D.M. KADIDLO, D.H. MCKENNA, J.S. BROMBERG, B.L. LEVINE, J.L. RILEY, C.H. JUNE, P. SCHEINBERG, D.C. DOUEK, J.S. MILLER, J.E. WAGNER, B.R. BLAZAR. Massive ex vivo expansion of human natural regulatory $T$ cells (T(regs)) with minimal loss of in vivo functional activity. Sci Transl Med, 3 (83), 83ra41 (2011).

62. A. BERES, R. KOMOROWSKI, M. MIHARA, W.R. DROBYSKI. Instability of Foxp3 expression limits the ability of induced regulatory $\mathrm{T}$ cells to mitigate graft versus host disease. Clin Cancer Res, 17 (12), 3969-3983 (2011).

63. J. CAO, C. CHEN, L. ZENG, L. LI, Z. LI, K. XU. Engineered regulatory $\mathrm{T}$ cells prevent graft-versus-host disease while sparing the graft-versus-leukemia effect after bone marrow transplantation. Leuk Res, 34 (10), 1374-1382 (2010).

64. M. LECLERC, S. NASERIAN, C. PILON, A. THIOLAT, G.H. MARTIN, C. POUCHY, C. DOMINIQUE, Y. BELKACEMI, F. CHARLOTTE, S. MAURY, B.L. SALOMON, J.L. COHEN. Control of GVHD by regulatory $\mathrm{T}$ cells depends on TNF produced by $\mathrm{T}$ cells and TNFR2 expressed by regulatory T cells. Blood, 128 (12), 1651-1659 (2016).

65. B.M. MATTA, D.K. REICHENBACH, X. ZHANG, L. MATHEWS, B.H. KOEHN, G.K. DWYER, J.M. LOTT, F.M. UHL, D. PFEIFER, C.J. FESER, M.J. SMITH, Q. LIU, R. ZEISER, B.R. BLAZAR, H.R. TURNQUIST. Peri-alloHCT IL-33 administration 
expands recipient T-regulatory cells that protect mice against acute GVHD. Blood, 128 (3), 427-439 (2016).

66. R. RAMLAL, G.C. HILDEBRANDT. Advances in the Use of Regulatory T-Cells for the Prevention and Therapy of Graft-vs.-Host Disease. Biomedicines, 5 (2), (2017).

67. A. THEIL, S. TUVE, U. OELSCHLAGEL, A. MAIWALD, D. DOHLER, D. OSSMANN, A. ZENKEL, C. WILHELM, J.M. MIDDEKE, N. SHAYEGI, K. TRAUTMANN-GRILL, M. VON BONIN, U. PLATZBECKER, G. EHNINGER, E. BONIFACIO, M. BORNHAUSER. Adoptive transfer of allogeneic regulatory $\mathrm{T}$ cells into patients with chronic graft-versushost disease. Cytotherapy, 17 (4), 473-486 (2015).

68. S. RANJAN, A. GOIHL, S. KOHLI, I. GADI, M. PIERAU, K. SHAHZAD, D. GUPTA, F. BOCK, H. WANG, H. SHAIKH, T. KAHNE, D. REINHOLD, U. BANK, A.C. ZENCLUSSEN, J. NIEMZ, T.M. SCHNODER, M. BRUNNER-WEINZIERL, T. FISCHER, T. KALINSKI, B. SCHRAVEN, T. LUFT, J. HUEHN, M. NAUMANN, F.H. HEIDEL, B. ISERMANN. Activated protein $\mathrm{C}$ protects from GvHD via PAR2/PAR3 signalling in regulatory T-cells. Nat Commun, 8 (1), 311 (2017).

69. A. PIERINI, L. COLONNA, M. ALVAREZ, D. SCHNEIDAWIND, H. NISHIKII, J. BAKER, Y. PAN, M. FLOREK, B.S. KIM, R.S. NEGRIN. Donor Requirements for Regulatory $\mathrm{T}$ Cell Suppression of Murine Graft-versus-Host Disease. J Immunol, 195 (1), 347-355 (2015).

70. D. SCHNEIDAWIND, J. BAKER, A. PIERINI, C. BUECHELE, R.H. LUONG, E.H. MEYER, R.S. NEGRIN. Third-party CD4+ invariant natural killer T cells protect from murine GVHD lethality. Blood, 125 (22), 3491-3500 (2015).

71. B.S. KIM, H. NISHIKII, J. BAKER, A. PIERINI, D. SCHNEIDAWIND, Y. PAN, A. BEILHACK, C.G. PARK, R.S. NEGRIN. Treatment with agonistic DR3 antibody results in expansion of donor Tregs and reduced graft-versus-host disease. Blood, 126 (4), 546-557 (2015).

72. J. SCHLODER, C. BERGES, A. TUETTENBERG, H. JONULEIT. Novel Concept of CD4-Mediated Activation of Regulatory $\mathrm{T}$ Cells for the Treatment of Graft-Versus-Host Disease. Front Immunol, 8, 1495 (2017).

73. M. KOYAMA, R.D. KUNS, S.D. OLVER, K.E. LINEBURG, M. LOR, B.E. TEAL, N.C. RAFFELT, L. LEVEQUE, C.J. CHAN, R.J. ROBB, K.A. MARKEY, K.A. ALEXANDER, A. VARELIAS, A.D. CLOUSTON, M.J. SMYTH, K.P. MACDONALD, G.R. HILL. Promoting regulation via the inhibition of DNAM-1 after transplantation. Blood, 121 (17), 3511-3520 (2013).
74. M. EDINGER. Driving allotolerance: CAR-expressing Tregs for tolerance induction in organ and stem cell transplantation. J Clin Invest, 126 (4), 1248-1250 (2016).

75. Y.C. KIM, A.H. ZHANG, Y. SU, S.A. RIEDER, R.J. ROSSI, R.A. ETTINGER, K.P. PRATT, E.M. SHEVACH, D.W. SCOTT. Engineered antigen-specific human regulatory $\mathrm{T}$ cells: immunosuppression of FVIIIspecific T- and B-cell responses. Blood, 125 (7), 11071115 (2015).

76. J. YOON, A. SCHMIDT, A.H. ZHANG, C. KONIGS, Y.C. KIM, D.W. SCOTT. FVIII-specific human chimeric antigen receptor T-regulatory cells suppress $\mathrm{T}$ - and B-cell responses to FVIII. Blood, 129 (2), 238-245 (2017).

77. A.C. FOKS, A.H. LICHTMAN, J. KUIPER. Treating atherosclerosis with regulatory $\mathrm{T}$ cells. Arterioscler Thromb Vasc Biol, 35 (2), 280-287 (2015).

78. O.J. DE BOER, J.J. VAN DER MEER, P. TEELING, C.M. VAN DER LOOS, A.C. VAN DER WAL. Low numbers of FOXP3 positive regulatory $T$ cells are present in all developmental stages of human atherosclerotic lesions. PLoS One, 2 (8), e779 (2007).

79. A. MOR, G. LUBOSHITS, D. PLANER, G. KEREN, J. GEORGE. Altered status of CD4(+)CD25(+) regulatory $\mathrm{T}$ cells in patients with acute coronary syndromes. Eur Heart J, 27 (21), 2530-2537 (2006).

80. A.C. FOKS, V. FRODERMANN, M. TER BORG, K.L. HABETS, I. BOT, Y. ZHAO, M. VAN ECK, T.J. VAN BERKEL, J. KUIPER, G.H. VAN PUIJVELDE. Differential effects of regulatory $\mathrm{T}$ cells on the initiation and regression of atherosclerosis. Atherosclerosis, 218 (1), 53-60 (2011).

81. J. LI, X. ZHAO, S. ZHANG, S. WANG, P. DU, G. QI. ApoB-100 and HSP60 peptides exert a synergetic role in inhibiting early atherosclerosis in immunized ApoE-null mice. Protein Pept Lett, 18 (7), 733-740 (2011).

82. G.H. VAN PUIJVELDE, A.D. HAUER, P. DE VOS, R. VAN DEN HEUVEL, M.J. VAN HERWIJNEN, R. VAN DER ZEE, W. VAN EDEN, T.J. VAN BERKEL, J. KUIPER. Induction of oral tolerance to oxidized low-density lipoprotein ameliorates atherosclerosis. Circulation, 114 (18), 1968-1976 (2006).

83. C. CABELLO-KINDELAN, S. MACKEY, A.L. BAYER. Adoptive $\mathrm{T}$ Regulatory Cell Therapy for Tolerance Induction. Curr Transplant Rep, 2 (2), 191-201 (2015).

84. A. TANAKA, S. SAKAGUCHI. Regulatory T cells in cancer immunotherapy. Cell Res, 27 (1), 109-118 (2017).

85. http://www.onestudy.org/ [Online]. [Accessed Nov. 2017]. 